\title{
Sensitivity of Venturia inaequalis Populations to Anilinopyrimidine Fungicides and Their Contribution to Scab Management in New York
}

\author{
Wolfram Köller, W. F. Wilcox, and D. M. Parker, Department of Plant Pathology, Cornell University, New York \\ State Agricultural Experiment Station, Geneva 14456
}

\begin{abstract}
Köller, W., Wilcox, W. F., and Parker, D. M. 2005. Sensitivity of Venturia inaequalis populations to anilinopyrimidine fungicides and their contribution to scab management in New York. Plant Dis. 89:357-365.

Sensitivities of Venturia inaequalis isolates to the anilinopyrimidine fungicides (APs) pyrimethanil and cyprodinil were determined for nine populations by measuring the growth of colonies formed from germinating conidia derived from single scab lesions. At the discriminatory pyrimethanil dose of $0.2 \mu \mathrm{g} \mathrm{ml}^{-1}$, the mean relative growth range measured for eight $V$. inaequalis populations ( $n=39$ to 74 ) never treated with AP fungicides varied from 18.1 to 48.2, translating into an approximately sixfold difference in mean baseline sensitivities. For the composite of all 469 isolates tested, sensitivities to pyrimethanil and to the sterol demethylation inhibitor (DMI) myclobutanil were significantly correlated. When isolates were organized into subpopulations based on their sensitivities to an individual fungicide, sensitivities to both fungicides declined in parallel through the highly and moderately sensitive spectra of subpopulations, but they diverged for isolates in subpopulations least sensitive to either fungicide. The result suggested that at least one of the multiple genes conferring DMI resistance also lowered the sensitivity to AP fungicides. The relative contribution of AP fungicides to scab management was evaluated at an experimental orchard representative of the Great Lakes region of the United States. Frequencies of DMI-resistant isolates of $V$. inaequalis had progressed to the stage of practical resistance at the site, and the sensitivity to pyrimethanil was similar to several commercial orchard populations never treated with APs. For management programs at the experimental site involving the AP fungicides cyprodinil and pyrimethanil and conducted from 1996 to 2000, the level of fruit and terminal leaf scab control was inferior to that of nonspecific protectants such as mancozeb or captan. For the control of scab on cluster leaves, the efficacy of AP fungicides equaled the performance of nonspecific protectants. This modest contribution of AP fungicides to scab management might have been caused by a lack of the extended cool temperature conditions that were conducive to AP performance in northern Europe in previous studies, and/or by the reduced sensitivity to AP fungicides in this DMI-resistant $V$. inaequalis population.
\end{abstract}

The class of anilinopyrimidine (AP) fungicides represented by pyrimethanil, mepanipyrim, and cyprodinil was introduced in the early 1990 s (22). They are in current use for the management of gray mold caused by Botrytis spp. and tree fruit diseases such as apple scab and brown rot $(15,35,41,44)$. In addition, cyprodinil is employed in the control of cereal diseases such as eyespot (15). APs were shown to act as weak inhibitors of spore germination, appressorium formation, and cuticle penetration, with disease development arrested after the respective hosts had been invaded $(8,9,20,31)$. This physical mode of

Corresponding author: W. Köller

E-mail: WK11@cornell.edu

Accepted for publication 2 November 2004.

DOI: 10.1094/PD-89-0357

(c) 2005 The American Phytopathological Society action suggested a primary target site in postpenetration steps of pathogen development.

Thus far, the biochemical mode of AP action has only been investigated for $\mathrm{Bo}$ trytis cinerea (teleomorph Botryotinia fuckeliana). Inhibitory potencies of APs under in vitro test conditions were low on growth media containing complex components such as yeast or malt extract, whereas growth on minimal media increased sensitivities of $B$. cinerea isolates more than 100-fold $(17,34)$. On such minimal media, AP action was strongly antagonized by methionine and the methionine precursor homocysteine, suggesting a target site in methionine biosynthesis $(13,36)$. The interference of cyprodinil with the regulation of methionine biosynthesis rather than the direct inhibition of candidate enzymes has been suggested recently (47). Alternatively, pyrimethanil and mepanipyrim were found to inhibit the secretion of extracellular enzymes $(37,38)$.
Mepanipyrim employed at relatively high doses was also reported to affect steps of intracellular protein trafficking in human cell cultures $(39,40)$, a finding in support of a potential target site of APs in protein secretion. Although the relative importance of these different mode-of-action models has not been elucidated, strict cross resistance among all members of the AP class $(5,16)$ suggests a common mode of action for $B$. cinerea.

The development of practical resistance to APs has been documented for $B$. cinerea. Here, the selection of phenotypes highly resistant to APs was identified as a rapid population response $(2,11,12,16,17$, $32,33)$. A single gene governed this trait of high-level resistance $(5,16)$, and a mutational change in the regulation of methionine biosynthesis was suggested as a potential mechanism of resistance (47).

Reports describing AP resistance of other pathogens are scarce in comparison to the information available for $B$. cinerea. In the control of cereal eyespot caused by Pseudocercosporella herpotrichoides (teleomorphs Tapesia yallundae and Tapesia acuformis) with cyprodinil, experimental field trials over several years gave no indication for the selection of isolates leading toward practical resistance to this fungicide (1). However, one isolate expressing a resistance factor $>50$ in in vitro tests was identified. As with $B$. cinerea, resistance was governed by a single gene (1).

APs are also in worldwide use for the management of apple scab caused by Venturia inaequalis (Cooke) G. Wint. $(6,7,30)$. In sensitivity tests involving mixed conidia populations of $V$. inaequalis collected from experimental orchards, it was found that up to $43 \mathrm{AP}$ treatments applied over several years had no measurable effect on population sensitivities (31), a finding interpreted as an indication for a low risk of resistance. In other surveys of population sensitivities also conducted with mixed conidia populations, sensitivity shifts in response to treatments with cyprodinil were described as significant, leading to the recommendation that the number of AP applications should be restricted to four per season (30). In tests determining the pyrimethanil sensitivities of single $V$. inaequalis isolates, the range of sensitivities 
was broad and separated by a factor of $>100$, a result attributed to the growth medium employed (45).

In this study, we describe the AP sensitivity of $V$. inaequalis baseline populations in New York, a partial correlation of isolate responses to the AP pyrimethanil and the sterol demethylation inhibitor (DMI) myclobutanil, and the contributions of cyprodinil and pyrimethanil to the management of apple scab in a DMI-resistant New York experimental orchard representative of the Great Lakes region of apple production in the United States.

\section{MATERIALS AND METHODS}

Materials. Pyrimethanil, cyprodinil, and myclobutanil were obtained from their respective manufacturers as technical products used in sensitivity tests or as formulated products used in orchard trials. Potato dextrose agar (PDA) and Bacto agar were purchased from Difco Laboratories (Detroit, MI). Disposable petri dishes (100 $\times 15 \mathrm{~mm}$ ) were from Fisher Scientific (Pittsburgh, PA). All other chemicals were from Sigma Chemical Company (St. Louis, MO).

Origin of $\boldsymbol{V}$. inaequalis isolates. The populations described in this study originated from 12 different apple orchards:

Baseline isolates. For sensitivity tests aimed at defining an appropriate discriminatory test dose for pyrimethanil, 22 monoconidial isolates collected in 2001 (Michigan) and 2002 (Pennsylvania) and described previously (26) were used. They were selected according to their typical baseline sensitivities to fenarimol or myclobutanil and to trifloxystrobin (26).

Wild-type populations. Isolates originated from apple trees never treated with fungicides and located in the western part of New York. Population 1 originated from backyard trees in Tompkins County, which were never treated with fungicides. The backyard was separated from commercial apple orchards by a distance of approximately $10 \mathrm{~km}$. Population 2 originated from the Montezuma National Wildlife Refuge, Seneca County, as described previously (48). Diseased leaves were collected from both locations in June 2003.

Abandoned. Isolates originated from an abandoned apple orchard. Commercial apple production and use of fungicides had been discontinued for over 20 years. The abandoned site was located near Highland, NY. Diseased leaves were collected in June 2003.

Vicinity. Diseased leaves were collected in June 2003 from a row of apple trees on the campus of the New York State Agricultural Experiment Station, Geneva, NY. The trees had never been treated with fungicides, but they were located in the vicinity (500 $\mathrm{m}$ distance) of an experimental apple orchard described previously (27).

Commercial orchards. The commercial orchards sampled were located in the Lake
Ontario region of Wayne County (NY and $\mathrm{W})$ and the Hudson/Champlain Valley region of New York (B, R, CP). The orchards were chosen because the measured incidence of fruit scab in 2002 was substantially above a commercially acceptable level $(>10 \%)$. All five orchards had been treated for over 10 years with DMI fungicides, but none had been treated with AP fungicides. Diseased leaves were collected from trees left unsprayed until the first leaf scab developed, according to a sampling procedure described previously (27).

Experimental. This research orchard at the New York State Agricultural Experiment Station was planted in 1974 and consists of alternating 'McIntosh' and 'Cortland' trees grafted onto MM. 106 rootstock. The orchard serves as an experimental site for fungicide efficacy trials. DMI fungicides have been used in the management of apple scab in randomized plots since 1976 (48), and AP fungicides were tested first in 1994. Diseased leaves were collected in June 2003 from nontreated 'McIntosh' trees.

Tests of fungicide sensitivities. Sensitivities of $V$. inaequalis isolates to pyrimethanil, cyprodinil, and myclobutanil were tested for mycelial colonies developing from germinating conidia after 7 days of incubation at $20^{\circ} \mathrm{C}$, following a procedure described previously (26). Conidia representing baseline isolates collected in 2001 and 2002 were prepared from mycelia as described previously (42). For all conidia samples collected in 2003, distinct lesions were cut from approximately 60 diseased leaves per sampling site, leaf disks were placed into Eppendorf tubes, and conidia were suspended by shaking (26).

Suspensions of conidia $(100 \mu \mathrm{l})$ were spread over the surfaces of either PDA or Czapek's medium (25) amended with Bacto agar $(1.5 \%)$. The suspensions contained approximately $10^{4}$ conidia for tests conducted on fungicide-amended media and approximately $10^{3}$ conidia for nonamended controls. All agar media contained antibiotics as described previously (48). Sizes of colonies formed after incubation for 7 days at $20^{\circ} \mathrm{C}$ were measured after magnification as described previously (26). For each test, the sizes of five colonies were measured at the points of their largest expansion. Relative growth (RG) values were defined as mean colony expansion (treated)/mean colony expansion (nontreated) $\times 100$.

In order to determine the effective dose for $50 \%$ growth inhibition $\left(\mathrm{ED}_{50}\right)$ for pyrimethanil and cyprodinil, agar media were amended with the fungicides dissolved in acetone to yield final concentrations of $0.001,0.003,0.01,0.03,0.1,0.3$, 1,3 , and $10 \mu \mathrm{g} \mathrm{ml}^{-1}$. For conidial suspensions derived from scab lesions sampled in 2003, the discriminatory test doses employed were $0.2 \mu \mathrm{g} \mathrm{ml}^{-1}$ for pyrimethanil as deduced from mean $\mathrm{ED}_{50}$ values of baseline populations, and $0.1 \mu \mathrm{g} \mathrm{ml}^{-1}$ for myclobutanil as described previously $(26,29)$. All final acetone concentrations were adjusted to $0.01 \%$ ( $\mathrm{vol} / \mathrm{vol})$.

Evaluation of fungicide performance. In the experimental orchard, fungicide treatments were arranged in a randomized complete block design with four replications. Each experimental unit consisted of a single 'McIntosh' tree. Spray solutions were applied dilute (2,800 liters/ha) to runoff with a handgun. Unless indicated otherwise, test fungicides were applied during the primary scab season, starting soon after bud break and ending 1 to 2 weeks after the completion of bloom (5256). Test fungicides were cyprodinil (Vangard 75WP), pyrimethanil (Scala 40SC), trifloxystrobin (Flint 50WG), mancozeb (Dithane 75DF), and captan (Captan 50 WP). Disease management programs were continued with four to five cover sprays of benomyl (Benlate 50WP; $210 \mathrm{~g}$ a.i./ha) mixed with captan (Captan 50W; 1,700 g a.i./ha), which were applied to all treated trees using an airblast sprayer. Apple scab incidence on leaves was evaluated by examining all leaves on 25 fruit clusters per tree in June or July, on all leaves of 10 shoots per tree in August, and on 100 fruits per tree at the same two times.

Data analysis. As described previously (29), sensitivities of $V$. inaequalis isolates comprising distinct subpopulations were compared by independent $t$ test analysis. Categorical sensitivity data were compared by fitting log-linear models with numbers of isolates grouped into separate sensitivity categories. $\mathrm{ED}_{50}$ values were calculated from the log-linear correlation of fungicide concentrations and RG values. Additive interactions between mixture components were analyzed by applying the formula $E_{\mathrm{xp}}$ $=X+Y-X Y / 100$, with $E_{\mathrm{xp}}$ as the percentage of control expected from additive effects of the two mixture components, and with $X$ and $Y$ as the percentages of control provided by the mixture components applied individually (43).

\section{RESULTS}

Dose responses of baseline isolates to pyrimethanil. $\mathrm{ED}_{50}$ values of baseline isolates to pyrimethanil $(n=22)$ were distributed narrowly, ranging from 0.12 to 0.3 $\mu \mathrm{g} \mathrm{ml}^{-1}$ (mean $\mathrm{ED}_{50}=0.16 \pm 0.4$ ). This narrow range of sensitivities was accompanied by a steep dose response for all isolates tested, as illustrated in Figure 1 for three representative isolates. For pyrimethanil at $1 \mu \mathrm{g} \mathrm{ml}^{-1}$, the inhibition of colony expansion was $\geq 95 \%$ for 20 of the 22 isolates tested, while strong $(>80 \%)$ yet incomplete inhibition at increasingly higher doses was observed for the remaining two isolates tested, as illustrated in Figure 1 for one isolate.

In order to examine the impact of growth medium on in vitro sensitivities of 
$V$. inaequalis isolates, as reported for $B$. cinerea isolates $(17,34)$, we tested the sensitivities of the same 22 isolates on minimal Czapek's medium. The mean colony growth in the absence of fungicide was reduced to $47 \%(P<0.001)$ of the growth supported by PDA. However, at the discriminatory pyrimethanil dose of $0.2 \mu \mathrm{g}$ $\mathrm{ml}^{-1}$, the mean RG value was $21 \pm 19$ and not different $(P=0.99)$ from the value of $21 \pm 22$ determined on PDA. The result suggested that the composition of the two growth media examined had no significant effect on the inhibitory potency of pyrimethanil. PDA was, therefore, employed in the sensitivity tests described below.

Pyrimethanil and cyprodinil sensitivities of $\boldsymbol{V}$. inaequalis populations. For the quantification of population sensitivities, pyrimethanil was employed at a discriminatory dose of $0.2 \mu \mathrm{g} \mathrm{ml}^{-1}$, reflecting a concentration slightly higher than the mean $\mathrm{ED}_{50}$ of the baseline isolates described above. The mean RG values determined for wild-type populations 1 and 2 were 16.8 ( $n$ $=46)$ and $20.3(n=28)$, respectively. These mean RG values were not significantly different $(P=0.22)$, thus the data were combined to represent a wild-type composite population never treated with fungicides (Table 1 and Fig. 2).

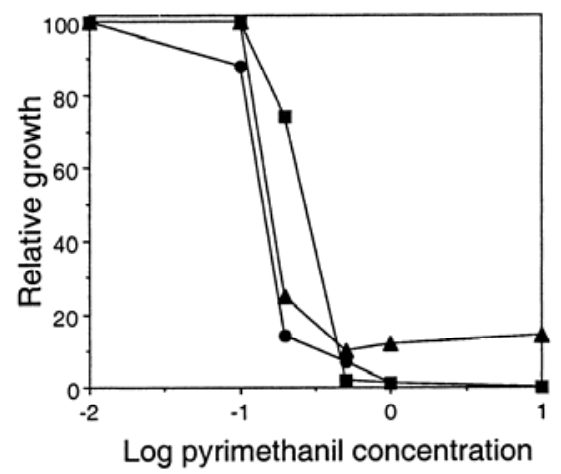

Fig. 1. Dose responses of three representative baseline isolates of Venturia inaequalis to pyrimethanil. Pyrimethanil concentrations are given in $\mu \mathrm{g} \mathrm{ml}^{-1}$.
The mean RG values determined for populations sampled from an abandoned orchard (Abandoned), from a row of nonmanaged apple trees in the vicinity of an experimental orchard (Vicinity), and from five commercial orchards located in different regions of New York ranged from 19.0 to 48.2 (Table 1). None of these populations had been treated with AP fungicides prior to sampling, and thus they reflected baseline populations. The RG value determined for an experimental orchard where AP performance had been tested since 1994 was 42.0 , and thus fell into the upper range of baseline sensitivities (Table 1). With the exception of one population sampled from a commercial orchard (NY), all mean RG values were significantly greater than for the wild-type population (Table 1).

The mean RG values of two populations ( $\mathrm{R}$ and $\mathrm{CP}$ ) were either not different from or higher than the RG value determined for the experimental orchard with its prolonged history of AP use (Table 1). Data from these three populations were combined to provide a composite for comparison with the wild-type population. The frequency distributions of the two isolate sensitivities overlapped (Fig. 2), as is typical for quantitative responses of populations to fungicide treatments $(21,23)$. Both the mean RG values (18.1 and 44.3) and the frequency distribution of isolate sensitivities were significantly different $(P<0.001)$.

In order to quantify sensitivity differences represented within the two composite populations, $\mathrm{ED}_{50}$ values for both pyrimethanil and cyprodinil were determined for two separate mixtures of conidia derived from six scab lesions each, representing RG values of $27 \pm 3$ and $82 \pm 7$, respectively. For pyrimethanil, the $\mathrm{ED}_{50}$ values of these two mixtures of conidia were $0.11 \mu \mathrm{g} \mathrm{ml}^{-1}$ and $0.64 \mu \mathrm{g} \mathrm{ml}^{-1}$, respectively (Fig. 2). $\mathrm{ED}_{50}$ values of cyprodinil measured for the same mixtures of conidia were $0.004 \mu \mathrm{g} \mathrm{ml}^{-1}$ and $0.024 \mu \mathrm{g} \mathrm{ml}{ }^{-1}$, respectively, and thus reflected the same sixfold difference observed for pyrimethanil.
Myclobutanil sensitivity of $V$. inaequalis populations. All commercial orchards investigated in this study had been treated with DMI fungicides for up to 15 years, and adaptive responses of respective $V$. inaequalis populations to prolonged treatments with DMIs were anticipated (29). Therefore, the sensitivity to the DMI myclobutanil was tested for each orchard population.

As expected, the wild-type population displayed the lowest mean RG value for myclobutanil (Table 1). The DMI sensitivity of the $V$. inaequalis population collected from an abandoned orchard was not different from the wild-type population, while the population from a row of apple trees in the vicinity of an experimental orchard departed significantly from the wild-type sensitivity (Table 1). The row of apple trees near the experimental orchard had never been treated with DMI fungicides. However, the experimental orchard nearby was tested as less DMI-sensitive than baseline during surveys conducted from 1992 to 1994 (27), suggesting an

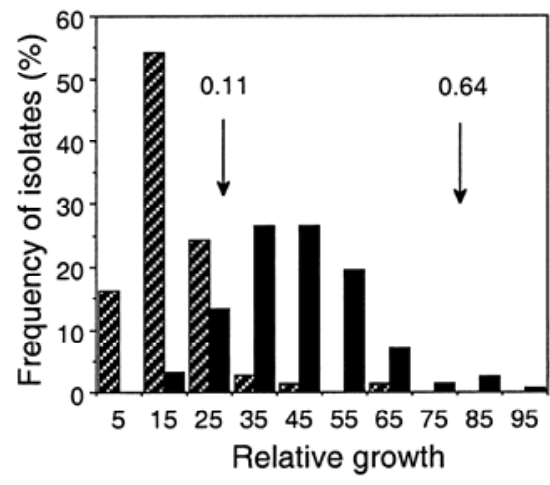

Fig. 2. Distribution of isolate sensitivities to pyrimethanil for two Venturia inaequalis composite populations. The populations described are a wild-type population (hatched bars, $n=$ 74) and a composite population characterized by significantly lower sensitivity (closed bars, $n=$ 159). Sensitivities are expressed as relative growth (RG) at a discriminatory pyrimethanil dose of $0.2 \mu \mathrm{g} \mathrm{ml}^{-1}$. $\mathrm{ED}_{50}$ values $\left(\mu \mathrm{g} \mathrm{ml}^{-1}\right)$ corresponding to RG values of 27 and 82 are provided above arrows.

Table 1. Sensitivity of Venturia inaequalis populations to pyrimethanil and myclobutanil

\begin{tabular}{|c|c|c|c|c|c|c|c|c|c|}
\hline \multirow[b]{2}{*}{ Population } & \multirow[b]{2}{*}{$n$} & \multirow[b]{2}{*}{ AP history $^{w}$} & \multicolumn{3}{|c|}{ Pyrimethanil } & \multicolumn{4}{|c|}{ Myclobutanil } \\
\hline & & & Mean RG & $P_{\mathrm{WT}^{\mathrm{x}}}^{\mathrm{x}}$ & $\boldsymbol{P}_{\mathbf{E X P}} \mathbf{P}^{\mathrm{y}}$ & DMI historyw $^{\text {w }}$ & Mean RG & $P_{\mathrm{WT}^{\mathrm{x}}}$ & $P_{\mathrm{EXP}^{\mathrm{y}}}$ \\
\hline Wild-type & 74 & - & 18.1 & - & $\mathrm{hs}^{\mathrm{z}}$ & - & 20.1 & - & hs \\
\hline Abandoned & 45 & - & 26.4 & hs & hs & - & 21.7 & 0.37 & hs \\
\hline Vicinity & 39 & - & 31.6 & hs & 0.003 & - & 46.5 & $\mathrm{hs}$ & 0.003 \\
\hline Commercial NY & 51 & - & 19.0 & 0.60 & hs & + & 47.9 & hs & 0.001 \\
\hline Commercial W & 55 & - & 30.0 & $\mathrm{hs}$ & hs & + & 50.1 & hs & 0.003 \\
\hline Commercial B & 46 & - & 31.0 & hs & hs & + & 63.0 & hs & 0.20 \\
\hline Commercial R & 45 & - & 42.7 & $\mathrm{hs}$ & 0.77 & + & 33.3 & hs & hs \\
\hline Commercial CP & 53 & - & 48.2 & hs & 0.03 & + & 59.5 & hs & 0.87 \\
\hline Experimental & 61 & + & 42.0 & $\mathrm{hs}$ & - & + & 59.0 & hs & - \\
\hline
\end{tabular}

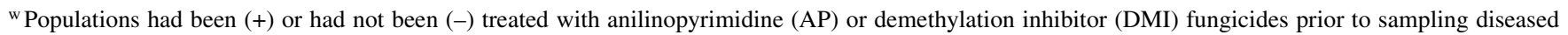
leaves subjected to sensitivity tests.

${ }^{x}$ Comparison of mean relative growth (RG) values ( $t$ test) with the wild-type population.

y Comparison of mean RG values ( $t$ test) with the population at the experimental orchard.

${ }^{\mathrm{z}}$ Highly significant $(P<0.001)$. 
influx of inoculum into the row of trees in question.

The experimental orchard described in the present study was diagnosed as fully DMI-resistant in 1998 (W. Köller and W. F. Wilcox, unpublished data), and a level of DMI-resistance exceeding the threshold of practical resistance was described in 2003 (26). Mean myclobutanil RG values determined for two of the five commercial orchards tested (B and CP) were not different from the experimental orchard, and thus conferred the status of practical DMI resistance. Mean RG values of populations recovered from the other three commercial orchards (NY, W, R) departed significantly from wild-type sensitivity, but DMI resistance remained below the level established for our experimental orchard (Table 1).
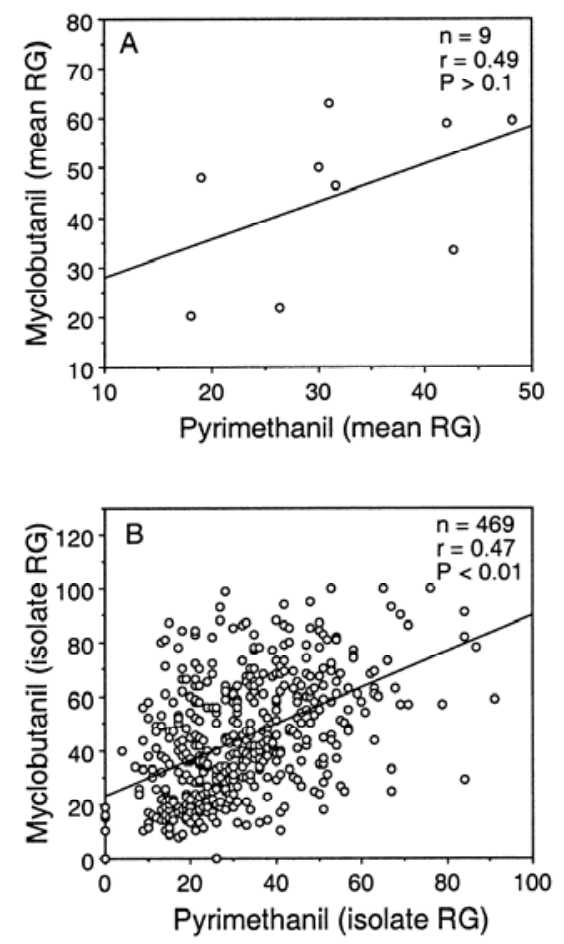

Fig. 3. Correlation of relative growth (RG) values determined for pyrimethanil and myclobutanil. A, Mean population RG values. B, $R G$ values for all individual isolates.
Interdependence of pyrimethanil and myclobutanil sensitivities. The significant variation of pyrimethanil sensitivity displayed by populations never treated with APs (Table 1) prompted us to analyze a potential relationship between isolate sensitivity to the AP pyrimethanil and the DMI myclobutanil. The correlation of mean pyrimethanil and myclobutanil RG values from the nine orchard populations was not significant (Fig. 3A), as reported previously for "bulk-sampled" populations of $V$. inaequalis retrieved from apple orchards in Europe (30). However, the correlation of pyrimethanil and myclobutanil sensitivities was significant when all isolate sensitivities determined in this study were included in the analysis (Fig. 3B).

In order to further analyze a potential relationship between isolate sensitivities to pyrimethanil and myclobutanil, mean RG values determined for myclobutanil were calculated for subpopulations delineated on the basis of decreasing RG values to pyrimethanil (Table 2). Because the two fungicides act independently, it was expected that myclobutanil sensitivities among these subpopulations would not be different. This assumption was not reflected in the respective data (Table 2). Myclobutanil RG values determined for the subpopulations most and least sensitive to pyrimethanil $(\mathrm{RG} \leq 10$ and $\mathrm{RG}>70$, respectively), were 24.7 and $71.0(P<$ 0.001 ) (Table 2), suggesting that isolate responses to the two fungicides were not independent. Indeed, myclobutanil and pyrimethanil sensitivities declined in parallel until pyrimethanil sensitivities reached RG values between 40 and 50 (Table 2).

This indication of partial cross sensitivity between the two independent fungicides was further supported by the converse analysis of mean pyrimethanil sensitivities among subpopulations defined by gradually declining myclobutanil sensitivities (Table 3). Again, isolate sensitivities to myclobutanil decreased in parallel to those of pyrimethanil up to RG values between 40 and 50 (Table 3), which reflect the mean sensitivities of $V$. inaequalis populations to pyrimethanil in DMIresistant orchards (Table 1).

Performance of AP fungicides in the management of apple scab. The partial correlation between pyrimethanil and myclobutanil sensitivities (Fig. 3, Tables 2 and 3 ) prompted us to analyze the relative contributions of AP fungicides to the management of scab in our fully DMI-resistant experimental orchard (Table 1). Cyprodinil had been tested on approximately 4 to $8 \%$ of the trees at this site for two seasons prior to the performance tests described below. Summaries of respective results have been communicated previously (5256).

Relative contribution of cyprodinil in mixture with mancozeb. For the management of apple scab in the United States, only cyprodinil is presently registered, with pyrimethanil pending registration. Cyprodinil is labeled for use alone or in a tank mixture with other fungicides. Applications of cyprodinil alone require the maximum label rate of $260 \mathrm{~g} / \mathrm{ha}$ and are restricted to the prebloom stage, whereas a rate of 160 to $260 \mathrm{~g} / \mathrm{ha}$ is labeled for use in tank mixtures. Performance levels achieved with these recommended programs were evaluated from 1996 to 2000 , with mancozeb chosen as the companion fungicide in tank-mixture treatments.

Due to heavy rain preventing fungicide applications during early spring of 1996, ascosporic infections occurred prior to the initiation of the scab management program. It was, therefore, expected that control provided by postinfection fungicides, such as the APs $(6,7,20)$, would be superior to that provided by purely protective fungicides, such as mancozeb. Indeed, a mixture of cyprodinil with mancozeb provided significant control of apple scab under these high-pressure conditions (Table 4).

However, when the two fungicides were applied singly at their respective mixture doses, the mancozeb component provided significantly more disease control on both fruits and terminal leaves than did cyprodinil, and each component provided equivalent control on cluster leaves. On

Table 2. Sensitivity to myclobutanil among subpopulations of Venturia inaequalis differing in their sensitivity to pyrimethanil

\begin{tabular}{|c|c|c|c|c|c|c|c|c|c|}
\hline \multirow{2}{*}{$\begin{array}{l}\text { Pyrimethanil } \\
\text { subpopulations }\end{array}$} & \multirow{2}{*}{$\begin{array}{c}\text { Mean RG } \\
\text { myclobutanily }\end{array}$} & \multicolumn{8}{|c|}{$\begin{array}{c}\text { Comparisons of mean RG values to myclobutanil among subpopulations } \\
\text { with declining pyrimethanil sensitivities }(P)^{\mathrm{w}}\end{array}$} \\
\hline & & 0-10 & $11-20$ & $21-30$ & $31-40$ & $41-50$ & $51-60$ & $61-70$ & $>70$ \\
\hline $0-10$ & 24.7 & - & & & & & & & \\
\hline $11-20$ & 32.6 & 0.08 & - & & & & & & \\
\hline $21-30$ & 38.7 & $\mathrm{hs}^{\mathrm{z}}$ & 0.02 & - & & & & & \\
\hline $31-40$ & 48.4 & hs & hs & hs & - & & & & \\
\hline $41-50$ & 56.2 & hs & hs & $\mathrm{hs}$ & 0.01 & - & & & \\
\hline $51-60$ & 56.8 & hs & hs & hs & 0.02 & 0.90 & - & & \\
\hline $61-70$ & 63.5 & hs & hs & hs & hs & 0.21 & 0.26 & - & \\
\hline$>70$ & 71.0 & hs & hs & hs & hs & 0.05 & 0.06 & 0.41 & - \\
\hline
\end{tabular}

${ }^{\mathrm{w}}$ Comparisons of mean relative growth (RG) values $(t$ test) to myclobutanil among pyrimethanil subpopulations.

${ }^{x}$ Subpopulations of isolates within the indicated ranges of RG values at the discriminatory dose of $0.2 \mu \mathrm{g} \mathrm{ml}^{-1}$.

${ }^{\mathrm{y}}$ Mean RG values at $0.1 \mu \mathrm{g} \mathrm{ml} \mathrm{l}^{-1}$ for isolates in the pyrimethanil subpopulations.

${ }^{\mathrm{z}}$ Highly significant $(P<0.001)$. 
both cluster leaves and fruit, the level of control provided by the mixture was extremely close to the theoretical value expected from additive effects (Table 4). Mean daily temperatures ranged from 3 to $19^{\circ} \mathrm{C}$ during the 35 -day period over which AP fungicides were applied; mean temps were $\leq 6^{\circ} \mathrm{C}$ on 4 days and $\geq 14^{\circ} \mathrm{C}$ on 13 days. The two temperatures of 6 and $14^{\circ} \mathrm{C}$ reflect the approximate borders of conditions unfavorable or optimal for the development of apple scab (49).
In 1997, treatments with fungicides were initiated 1 day prior to the first ascosporic infection period. A program consisting of two sprays of cyprodinil alone followed by four in combination with mancozeb provided significantly better disease control on cluster leaves than that provided by six applications of mancozeb alone employed at the mixture rate. However, the two programs provided equivalent control on fruit and terminal leaves (Table 5 ). When mancozeb was omitted from the final four sprays of the cyprodinil program, control of fruit and terminal leaf scab was significantly less than that provided by mancozeb alone, although control of cluster leaf scab was equivalent (Table 5). Between the first and last treatment with cyprodinil (51 days), mean daily temperatures ranged from 4 to $17^{\circ} \mathrm{C}$, with $\leq 6^{\circ} \mathrm{C}$ recorded at 5 days and $\geq 14^{\circ} \mathrm{C}$ at 9 days.

The experimental design was repeated in 1999, yielding very similar results. A cyprodinil program, initiated with two

Table 3. Sensitivity to pyrimethanil among subpopulations of Venturia inaequalis differing in their sensitivities to myclobutanil

\begin{tabular}{|c|c|c|c|c|c|c|c|c|c|c|c|}
\hline \multirow{2}{*}{$\begin{array}{l}\text { Myclobutanil } \\
\text { subpopulations }\end{array}$} & \multirow{2}{*}{$\begin{array}{c}\text { Mean RG } \\
\text { pyrimethanily }^{y}\end{array}$} & \multicolumn{10}{|c|}{$\begin{array}{c}\text { Comparisons of mean RG values to pyrimethanil among subpopulations } \\
\text { with declining myclobutanil sensitivities }(P)^{\mathrm{w}}\end{array}$} \\
\hline & & 0-10 & $11-20$ & $21-30$ & $31-40$ & $41-50$ & $51-60$ & $61-70$ & $71-80$ & $81-90$ & $>90$ \\
\hline $0-10$ & 13.5 & - & & & & & & & & & \\
\hline $11-20$ & 19.8 & $\mathrm{hs}^{\mathrm{z}}$ & - & & & & & & & & \\
\hline $21-30$ & 28.9 & hs & hs & - & & & & & & & \\
\hline $31-40$ & 29.2 & hs & hs & 0.89 & - & & & & & & \\
\hline $41-50$ & 33.2 & hs & hs & 0.07 & 0.06 & - & & & & & \\
\hline $51-60$ & 37.1 & hs & hs & $\mathrm{hs}$ & hs & 0.16 & - & & & & \\
\hline $61-70$ & 39.2 & hs & hs & hs & hs & 0.01 & 0.45 & - & & & \\
\hline $71-80$ & 41.6 & $\mathrm{hs}$ & hs & hs & hs & 0.02 & 0.29 & 0.50 & - & & \\
\hline $81-90$ & 40.8 & hs & hs & hs & hs & 0.03 & 0.39 & 0.69 & 0.80 & - & \\
\hline$>90$ & 49.3 & hs & hs & hs & hs & $\mathrm{hs}$ & 0.01 & 0.03 & 0.25 & 0.22 & - \\
\hline
\end{tabular}

${ }^{\mathrm{w}}$ Comparisons of mean relative growth (RG) values ( $t$ test) to pyrimethanil among myclobutanil subpopulations.

${ }^{x}$ Subpopulations of isolates within the indicated ranges of RG values at the discriminatory dose of $0.1 \mu \mathrm{g} \mathrm{ml}^{-1}$.

${ }^{\mathrm{y}}$ Mean RG values at $0.2 \mu \mathrm{g} \mathrm{ml}^{-1}$ for isolates in the myclobutanil subpopulations.

${ }^{\mathrm{z}}$ Highly significant $(P<0.001)$.

Table 4. Relative control of apple scab provided by cyprodinil and mancozeb in 1996

\begin{tabular}{|c|c|c|c|c|c|c|}
\hline \multirow[b]{2}{*}{ Treatment } & \multirow[b]{2}{*}{ Timing $^{\mathrm{v}}$} & \multirow{2}{*}{$\begin{array}{c}\begin{array}{c}\text { Rate } \\
\text { (g a.i./ha) }\end{array} \\
\end{array}$} & \multicolumn{2}{|c|}{ Fruit scab incidence $(\%)^{\mathrm{u}}$} & \multicolumn{2}{|c|}{ Leaf scab incidence $(\%)^{\mathrm{u}}$} \\
\hline & & & 16 July $^{\mathrm{w}}$ & 19 August $^{w}$ & 16 July $^{x}$ & 19 August $^{y}$ \\
\hline Check & & & $85.5 \mathrm{a}$ & $85.3 \mathrm{a}$ & $28.9 \mathrm{a}$ & $71.4 \mathrm{a}$ \\
\hline Cyprodinil & & 140 & & & & \\
\hline+ mancozeb & $1-6$ & 2,500 & $8.0 \mathrm{~b}(91)$ & $9.3 \mathrm{~b}(89)$ & 4.3 c (85) & $10.5 \mathrm{~b}(85)$ \\
\hline Mancozeb & $1-6$ & 2,500 & 14.3 b (83) & 16.8 b (80) & 10.4 b (64) & $6.6 \mathrm{~b}(91)$ \\
\hline Cyprodinil & $1-6$ & 140 & $45.0 \mathrm{c}(47)$ & 41.3 c (52) & $14.2 \mathrm{~b}(51)$ & $32.0 \mathrm{c}(55)$ \\
\hline Additive $^{z}$ & & & (91) & $(90)$ & $(82)$ & (96) \\
\hline
\end{tabular}

u Mean values from four replicate trees per treatment. Means within a column not followed by a common letter are significantly different $(P \leq 0.05)$ according to the Waller-Duncan $k$-ratio LSD rule. Values in parentheses denote percent control relative to the untreated check.

${ }^{\vee}$ Fungicides were applied on: $1=2$ May (early tight cluster); $2=8$ May (early pink bud); $3=15$ May (pink); $4=22$ May (bloom); $5=29$ May (petal fall); 6 = 5 June (first cover). Five additional applications of benomyl $(210 \mathrm{~g} / \mathrm{ha})$ plus captan $(1,700 \mathrm{~g} / \mathrm{ha})$ were applied on a 2 -week schedule, starting 18 June.

${ }^{\mathrm{w}}$ Incidence on 100 fruits per tree.

${ }^{x}$ Incidence on all leaves of 25 fruiting clusters per tree.

$\mathrm{y}$ Incidence on all leaves of 10 terminal shoots per tree.

${ }^{\mathrm{z}}$ Percent control expected from theoretical additive effects.

Table 5. Relative control of apple scab provided by cyprodinil and mancozeb in 1997

\begin{tabular}{|c|c|c|c|c|c|c|}
\hline \multirow[b]{2}{*}{ Treatment } & \multirow[b]{2}{*}{ Timing $^{w}$} & \multirow{2}{*}{$\begin{array}{c}\begin{array}{c}\text { Rate } \\
\text { (g a.i./ha) }\end{array} \\
\end{array}$} & \multicolumn{2}{|c|}{ Fruit scab incidence $(\%)^{\mathrm{v}}$} & \multicolumn{2}{|c|}{ Leaf scab incidence $(\%)^{v}$} \\
\hline & & & 27 June $^{x}$ & 18 August $^{x}$ & 27 June $^{\mathrm{y}}$ & 19 August $^{\mathrm{z}}$ \\
\hline Check & & & $91.8 \mathrm{a}$ & $99.1 \mathrm{a}$ & $63.1 \mathrm{a}$ & $99.8 \mathrm{a}$ \\
\hline Mancozeb & $1-6$ & 2,500 & 13.8 b (85) & $28.3 \mathrm{~b}(71)$ & 10.9 b (83) & $66.2 \mathrm{~b}(34)$ \\
\hline Cyprodinil & 1,2 & 260 & & & & \\
\hline Cyprodinil & $3-6$ & 160 & & & & \\
\hline+ mancozeb & & 2,500 & $15.3 \mathrm{~b}(83)$ & $22.5 \mathrm{~b}(77)$ & 6.5 c (90) & $45.2 \mathrm{~b}(55)$ \\
\hline Cyprodinil & 1,2 & 260 & & & & \\
\hline Cyprodinil & $3-6$ & 160 & 48.3 c (47) & $71.0 \mathrm{c}(27)$ & $18.7 \mathrm{~b}(70)$ & $84.2 \mathrm{c}(16)$ \\
\hline
\end{tabular}

${ }^{\mathrm{v}}$ Mean values from four replicate trees per treatment. Means within a column not followed by a common letter are significantly different $(P \leq 0.05)$ according to the Waller-Duncan $k$-ratio LSD rule. Values in parentheses denote percent control relative to the untreated check.

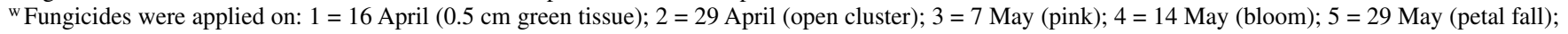
$6=5$ June (first cover). Five additional applications of benomyl $(210 \mathrm{~g} / \mathrm{ha})$ plus captan $(1,700 \mathrm{~g} / \mathrm{ha})$ were applied on a 2 -week schedule, starting $19 \mathrm{June}$.

${ }^{\mathrm{x}}$ Incidence on 100 fruits per tree.

y Incidence on all leaves of 25 fruiting clusters per tree.

${ }^{\mathrm{z}}$ Incidence on all leaves of 10 terminal shoots per tree. 
applications alone, followed by five applications in mixture with mancozeb provided significant control of scab. Omitting mancozeb from the cyprodinil program yielded levels of fruit scab control inferior to mancozeb alone, while control of scab on both cluster and terminal leaves was equivalent (Table 6). In 1999, mean temperatures during the scab management program (57 days) ranged from 3 to $26^{\circ} \mathrm{C}$, with $\leq 6^{\circ} \mathrm{C}$ recorded at 8 days and $\geq 14^{\circ} \mathrm{C}$ at 24 days.

In summary, the consistent results obtained during the 3 years of comparative performance tests revealed that the relative contributions of cyprodinil to scab management when used over the entire scab season according to the U.S. label were significantly lower than for a low-rate mancozeb in the control of fruit scab. In the control of terminal leaf scab assessed at the end of respective growing seasons, the relative contribution of cyprodinil was inferior (1996 and 1997) or equivalent (1999) to mancozeb. In the control of cluster leaf scab, performances of cyprodinil and mancozeb were equivalent.

Relative contributions of cyprodinil and pyrimethanil restricted to prebloom applications. In trials conducted in 1998 and 2000, applications of AP fungicides were restricted to the prebloom period, followed by a block of alternative fungicides. In order to assess the relative contributions of APs to the management of scab, the two early treatments with APs were, in comparative trials, either omitted or substituted.

In 1998, fungicide sprays did not begin until 7 days after the first infection period, which occurred as the fruit buds were beginning to break from dormancy. A program consisting of two cyprodinil applications followed by four of trifloxystrobin (79 g/ha) provided significant control of apple scab, but omitting the initial two cyprodinil applications did not affect any aspect of its performance (Table 7). In contrast, applying trifloxystrobin even at a lower rate $(53 \mathrm{~g} / \mathrm{ha})$ in all six sprays resulted in significantly less fruit scab 3 weeks after this part of the program was completed, indicating that conditions were suitable for disease development during the period the first two fungicide applications were made (Table 7).

In 2000, three prebloom applications of pyrimethanil were followed by four treatments with the protectant captan. With the exception of cluster leaf scab control, the performance of the program involving pyrimethanil was significantly lower than for the protectant captan applied alone over the entire course (Table 8). The re- sults suggested that the relative contribution of pyrimethanil to the block-spray program was inferior to captan used alone.

For the two scab seasons of 1998 and 2000, mean daily temperatures between first fungicide application and bloom were as follows: In 1998 (30 days), temperatures ranged from 3 to $19^{\circ} \mathrm{C}$, with 9 days at $\leq 6^{\circ} \mathrm{C}$ and 5 days at $\geq 14^{\circ} \mathrm{C}$. In 2000 (32 days), temperatures ranged from 0 to $23^{\circ} \mathrm{C}$, with 12 days at $\leq 6^{\circ} \mathrm{C}$ and 6 days at $\geq 14^{\circ} \mathrm{C}$.

\section{DISCUSSION}

In contrast to the considerable information documented for resistance of $B$. cinerea populations to AP fungicides $(5,11,12,16,17,32,33)$, few detailed studies have characterized responses of $V$. inaequalis populations to these fungicides. In the current report, we have, for the first time, documented pronounced differences in sensitivities to the AP pyrimethanil among baseline populations of this fungus. We furthermore have shown that mean sensitivities in six out of seven baseline orchard populations were significantly lower than that in a composite wild-type population, and we have established a statistical association between sensitivities of individual isolates to pyrimethanil and to the unrelated DMI fungicide, myclobu-

Table 6. Relative control of apple scab provided by cyprodinil and mancozeb in 1999

\begin{tabular}{|c|c|c|c|c|c|c|}
\hline \multirow[b]{2}{*}{ Treatment } & \multirow[b]{2}{*}{ Timingw } & \multirow{2}{*}{$\begin{array}{c}\text { Rate } \\
\text { (g a.i./ha) }\end{array}$} & \multicolumn{2}{|c|}{ Fruit scab incidence $(\%)^{\mathrm{v}}$} & \multicolumn{2}{|c|}{ Leaf scab incidence $(\%)^{\mathrm{v}}$} \\
\hline & & & 26 June $^{x}$ & 17 Augustx $^{x}$ & 26 June Ju $^{y}$ & 1 August $^{z}$ \\
\hline Check & & & $37.5 \mathrm{a}$ & $68.5 \mathrm{a}$ & $42.8 \mathrm{a}$ & $81.4 \mathrm{a}$ \\
\hline Mancozeb & $1-7$ & 2,500 & $10.0 \mathrm{~b}(73)$ & $12.3 \mathrm{~b}(82)$ & $33.4 \mathrm{ab}(22)$ & $43.0 \mathrm{~b}(34)$ \\
\hline Cyprodinil & 1,2 & 260 & & & & \\
\hline Cyprodinil & $3-7$ & 160 & & & & \\
\hline+ mancozeb & & 2,500 & $8.3 \mathrm{~b}(78)$ & $5.5 \mathrm{~b}(92)$ & $13.5 \mathrm{~b}(68)$ & $46.2 \mathrm{~b}(43)$ \\
\hline Cyprodinil & 1,2 & 260 & & & & \\
\hline Cyprodinil & $3-7$ & 160 & 30.0 c (20) & 30.3 c (46) & $22.8 \mathrm{~b}(46)$ & 49.7 b (39) \\
\hline
\end{tabular}

${ }^{\mathrm{v}}$ Mean values from four replicate trees per treatment. Means within a column not followed by a common letter are significantly different $(P \leq 0.05)$ according to the Waller-Duncan $k$-ratio LSD rule. Values in parentheses denote percent control relative to the untreated check.

${ }^{\mathrm{w}}$ Fungicides were applied on: $1=12$ April ( $0.5 \mathrm{~cm}$ green tissue); $2=23$ April (early tight cluster); $3=5 \mathrm{May}$ (pink); $4=13 \mathrm{May}$ (bloom); $5=20 \mathrm{May}$ (petal fall); $6=27$ May (first cover); $7=7$ June (second cover). Four additional applications of benomyl (210 g/ha) plus captan (1,700 g/ha) were applied on a 2week schedule, starting 18 June.

$\mathrm{x}$ Incidence on 100 fruits per tree.

${ }^{\mathrm{y}}$ Incidence on all leaves of 25 fruiting clusters per tree.

${ }^{\mathrm{z}}$ Incidence on all leaves of 10 terminal shoots per tree.

Table 7. Relative control of apple scab by cyprodinil and trifloxystrobin in 1998

\begin{tabular}{|c|c|c|c|c|c|c|}
\hline \multirow[b]{2}{*}{ Treatment } & \multirow[b]{2}{*}{ Timingw } & \multirow{2}{*}{$\begin{array}{c}\text { Rate } \\
\text { (g a.i./ha) }\end{array}$} & \multicolumn{2}{|c|}{ Fruit scab incidence $(\%)^{\mathrm{v}}$} & \multicolumn{2}{|c|}{ Leaf scab incidence $(\%)^{\mathrm{v}}$} \\
\hline & & & 15 June $^{x}$ & 11 August $^{\mathrm{x}}$ & 15 June $^{\mathrm{y}}$ & 11 August $^{\mathrm{z}}$ \\
\hline Check & & & $86.0 \mathrm{a}$ & $100 \mathrm{a}$ & $77.0 \mathrm{a}$ & $87.8 \mathrm{a}$ \\
\hline Cyprodinil & 1,2 & 260 & & & & \\
\hline Trifloxystrobin & $3-6$ & 79 & 20.7 c (76) & 30.5 c (70) & 19.7 c (74) & 20.5 c (78) \\
\hline Trifloxystrobin & $3-6$ & 79 & 23.5 c (73) & $38.8 \mathrm{c}(61)$ & 22.9 c (70) & 24.3 c (73) \\
\hline Trifloxystrobin & $1-6$ & 53 & $9.5 \mathrm{~d}(89)$ & $17.0 \mathrm{~d}(83)$ & 16.0 c (79) & $28.8 \mathrm{c}(68)$ \\
\hline
\end{tabular}

${ }^{\mathrm{v}}$ Mean values from four replicate trees per treatment. Means within a column not followed by a common letter are significantly different $(P \leq 0.05)$ according to the Waller-Duncan $k$-ratio LSD rule. Values in parentheses denote percent control relative to the untreated check.

${ }^{\mathrm{w}}$ Fungicides were applied on: $1=6$ April $(0.5 \mathrm{~cm}$ green tissue); $2=14$ April (early tight cluster); $3=24$ April (pink); $4=5 \mathrm{May}($ late bloom); $5=13 \mathrm{May}$ (petal fall); $6=26$ May (first cover). Four additional applications of benomyl (210 g/ha) plus captan $(1,700 \mathrm{~g} / \mathrm{ha}) \mathrm{were}$ applied on a 2 -week schedule, starting 5 June, with the exception of the continuous trifloxystrobin program, where the program was continued throughout the entire season.

${ }^{\mathrm{x}}$ Incidence on 100 fruits per tree.

$\mathrm{y}$ Incidence on all leaves of 25 fruiting clusters per tree.

${ }^{\mathrm{z}}$ Incidence on all leaves of 10 terminal shoots per tree. 
tanil. These results have both theoretical and practical implications.

Küng et al. (30), who analyzed "bulk samples" of $V$. inaequalis isolates obtained from European orchards, found no significant correlation between sensitivities to the AP fungicide cyprodinil and the DMI difenconazole. Analogously, when we compared the mean sensitivities to pyrimethanil and myclobutanil for our nine sample populations, we also found no statistically significant correlation. However, when we compared sensitivities to the two fungicides for each of the 469 individual isolates that comprised the total of isolates tested, a highly significant correlation emerged. This finding, which suggests the presence of a mechanism responsible for lowering sensitivities to two unrelated fungicides simultaneously, is consistent with our previous report that $V$. inaequalis phenotypes originally selected for resistance to dodine were apparently predisposed to selection for resistance to DMI fungicides (28), and with the correlation of sensitivities of Uncinula necator isolates to the QoI azoxystrobin and the DMI myclobutanil (57).

Although highly speculative at present, a gene conferring a low level of resistance to both pyrimethanil and myclobutanil might encode an ATP-binding cassette (ABC) transporter responsible for decreased intracellular concentrations of multiple fungicides, and overexpression of such genes has been reported to confer lowlevel resistance to multiple antifungal inhibitors $(10,50)$. For example, the transcription level of a particular ABC transporter gene of $B$. cinerea was strongly induced in response to treatments with different fungicides, including the AP cyprodinil and different DMIs (51). While the high-level resistance to APs described for $B$. cinerea was not affiliated with decreased AP uptake, low-level resistance described for the same pathogen was consistent with an $\mathrm{ABC}$ transporter-mediated restriction of fungicide uptake (5). Homologues of genes encoding $\mathrm{ABC}$ transporters have also been described for $V$. inaequalis (46).

The resistance factors conferred by genes encoding $\mathrm{ABC}$ transporters are in general small in comparison with mechanisms governing high levels of resistance $(10,50)$. However, they can be expected to have impact on the performance of independent classes of fungicides, if population responses follow the course of quantitative (multigenic) resistance $(21,23)$. As documented for the DMI fungicides, which serve as an example for the development of quantitative resistance $(23,24)$, several unrelated genes conferring a relatively small level of resistance each will collectively have a pronounced impact on the sensitivities of genotypes expressing most or all of the resistance genes in question. When exposed to the fungicide, respective genotypes will be selected over time until the status of practical resistance is reached $(24,29)$.

If one of the several genes responsible for DMI resistance lowers simultaneously the sensitivity to other fungicides, DMIresistant populations of $V$. inaequalis would, consequently, be also less sensitive to a new fungicide to which they had no previous exposure. In such cases, the level of scab control achieved with a new class of fungicides will likely depend on its recommended dose $(23,24,27)$. Doses of AP fungicides effective in DMI-sensitive populations might be less effective in populations in which genes conferring multiple resistance have already been selected to a high frequency, regardless of a relatively small factor of resistance conferred.

For example, it was documented that $V$. inaequalis phenotypes least sensitive to DMIs and selected toward practical DMI resistance were approximately 8 to 10 times less sensitive than typical baseline isolates (29), demonstrating that relatively small factors of resistance can be of practical importance. The mean sensitivity to the APs pyrimethanil and cyprodinil (as determined by characteristic $\mathrm{ED}_{50}$ values) was approximately sixfold lower in our experimental orchard than in the wild-type population, and was reflective of sensitivities in two of the five commercial orchards never treated with AP fungicides. Although such shifts are not of the magnitude reported from orchards in Europe exposed to prolonged cyprodinil use (i.e., >30-fold relative to baseline populations) (30), they may nevertheless be practically relevant.

Use strategies for the management of apple scab with APs were developed primarily in northern Europe $(6,7,30)$. In an early report of trials conducted in Belgium, pyrimethanil was rated as providing generally superior control relative to nonspecific protectants such as captan and mancozeb (6). Subsequently, it was noted (7) that postinfection activities of the APs are particularly pronounced when temperatures are low (near $6^{\circ} \mathrm{C}$ ) during and after an apple scab infection period. However, it also was noted that these fungicides provide better control of scab on leaves than on fruit. These various observations led to the recommendation that APs be used only until the end of bloom, in mixture with a protectant fungicide to provide additional protection of the fruit (7).

In our DMI-resistant experimental orchard located in the Great Lakes region of the United States, AP fungicides provided relatively modest benefits when we tested them in various programs according to the general guidelines. The relative contributions of both cyprodinil and pyrimethanil to control of cluster leaf scab were generally equivalent to that of the mancozeb or captan component in such programs, although mancozeb was usually applied at only half of the rate recommended when using this fungicide alone. In contrast, the APs provided significantly less control of fruit scab than did the protectants, and control of scab on the terminal leaves was consistently lower in treatments where only the APs were applied early in the season versus the complementary treatment receiving only the protectant.

Because most terminal leaves were formed after the treatment programs (and ascospore discharge) had ended, and all trees were subjected to an identical spray regime thereafter, these results suggest that the APs may have provided less reduction of secondary inoculum than did the protectants. Although this was not reflected by the ratings of cluster scab incidence conducted at the start of summer, it is possible that at least some of the control of early

Table 8. Relative control of apple scab provided by pyrimethanil and captan in 2000

\begin{tabular}{|c|c|c|c|c|c|c|}
\hline \multirow[b]{2}{*}{ Fungicide } & \multirow[b]{2}{*}{ Timingw } & \multirow{2}{*}{$\begin{array}{c}\text { Rate } \\
\text { (g a.i.//ha) }\end{array}$} & \multicolumn{2}{|c|}{ Fruit scab incidence $(\%)^{v}$} & \multicolumn{2}{|c|}{ Leaf scab incidence $(\%)^{\mathrm{v}}$} \\
\hline & & & 19 June $^{\mathrm{x}}$ & 21 August $^{x}$ & 19 June $^{y}$ & 21 August $^{z}$ \\
\hline $\begin{array}{l}\text { Check } \\
\text { Pyrimethanil }\end{array}$ & $1-3$ & 825 & $91.3 \mathrm{a}$ & $99.8 \mathrm{a}$ & $90.1 \mathrm{a}$ & $100 \mathrm{a}$ \\
\hline Captan & $3-7$ & 3,400 & $19.3 \mathrm{~b}(79)$ & $16.3 \mathrm{~b}(84)$ & $5.3 \mathrm{~b}(94)$ & $50.5 \mathrm{~b}(50)$ \\
\hline Captan & $1-7$ & 3,400 & 7.0 c (92) & $9.3 \mathrm{c}(91)$ & 2.5 b (97) & $29.4 \mathrm{c}(71)$ \\
\hline
\end{tabular}

${ }^{\mathrm{v}}$ Mean values from four replicate trees per treatment. Means within a column not followed by a common letter are significantly different $(P \leq 0.05)$ according to the Waller-Duncan $k$-ratio LSD rule. Values in parentheses denote percent control relative to the untreated check.

${ }^{\text {w}}$ Fungicides were applied on: $1=7$ April $(0.5 \mathrm{~cm}$ green tissue); $2=19$ April (early tight cluster); $3=1$ May (pink); $4=8$ May (bloom); $5=15$ May (petal fall); 6 = 25 May (first cover); 7 = 7 June (second cover). Four additional applications of benomyl ( $210 \mathrm{~g} / \mathrm{ha})$ plus captan $(1,700 \mathrm{~g} / \mathrm{ha})$ were applied on a 2 week schedule, starting 22 June.

${ }^{\mathrm{x}}$ Incidence on 100 fruits per tree.

${ }^{y}$ Incidence on all leaves of 25 fruiting clusters per tree.

${ }^{\mathrm{z}}$ Incidence on all leaves of 10 terminal shoots per tree. 
cluster leaf infection was transitory, i.e., these infections were merely suppressed rather than halted. Similar results concerning the relative contributions of AP fungicides and mancozeb have been reported recently from a DMI-resistant site in Michigan (19), although these workers also showed the superiority of APs for early postinfection control on cluster leaves (18).

Two factors might explain the discrepancy between AP performance described here and studies conducted in Europe. AP fungicides were found most effective at long periods with temperatures around $6^{\circ} \mathrm{C}$ (7), reflecting the transition from unfavorable to favorable conditions for scab development (49). Such climatic conditions are not common during the relevant portion of the year in the Great Lakes region of the United States. Of the total of 205 days spanning the periods between applications of APs in the 5 years of orchard trials described here, only 38 days had median daily temperatures $\leq 6^{\circ} \mathrm{C}$. The duration of these periods never exceeded four consecutive days, and they were counterbalanced by longer periods (57 days) of temperatures $\geq 14^{\circ} \mathrm{C}$ comprising optimal conditions for scab development (49). Consequently, the climatic conditions conducive to good control of apple scab by APs are less common in the Great Lakes region of the United States or climatically similar regions than they are in the northern part of Europe. For example, comparatively weak performance of pyrimethanil in scab control has been reported recently for experimental orchards in Italy (4).

It must be mentioned that evidence for a relationship between low temperatures and improved control of apple scab by AP fungicides is largely circumstantial. It has been suggested that low temperatures might prolong the effective period of curative activity for these compounds by slowing the development of the pathogen (7) and/or by limiting their volatility at higher temperatures and thereby increasing their period of residual protective activity (6).

As a second parameter with possible effects on AP performances, the isolate sensitivity of the $V$. inaequalis population in our experimental orchard was significantly lower than that for wild-type populations. Although the sensitivity difference was relatively small, frequencies of isolates least sensitive to APs were increased approximately 10 -fold at the experimental site, as typical for quantitative population responses to fungicides $(21,23)$. The departure from wild-type sensitivities at the experimental orchard site may have resulted from previous testing of AP fungicides, but these fungicides had been applied to just a small fraction of the orchard over only two seasons prior to the first of the consistent trials presented in this study. Therefore, and with the additional consideration that very similar AP sensitivities were detected in two of five commercial orchards never exposed to these materials, we believe that it is far more likely that the observed shift in AP sensitivities resulted from a selection of the $V$. inaequalis population in response to prolonged applications of DMI fungicides leading to practical DMI resistance. Thus, the impact of DMI resistance at the particular test site cannot be excluded as a major parameter affecting AP performances.

Because the AP sensitivity of the $V$. inaequalis population in our experimental orchard mimicked the population sensitivities in several commercial orchards never treated with APs, we conclude that our results are likely to reflect the relative contributions of AP fungicides to apple scab management in many commercial orchards in the Great Lakes region. At the recommended use rates of AP fungicides, we expect their contributions will be inferior (fruit scab) or largely equivalent (leaf scab) to the control provided by protectants such as mancozeb and captan. Consequently, their primary value in this region, or those with similar climates, is likely to reside in postinfection applications for the control of early cluster leaf infections in rotation with other specific fungicides, where the use of the nonspecific protectants is limited by considerations inherent to integrated pest management programs, such as the suppressive effects of mancozeb on predatory mite populations $(3,14)$ or the incompatibility of captan with mineral oil treatments.

In summary, the results described in this study integrate a detailed analysis of $V$. inaequalis baseline sensitivities to AP fungicides with their intrinsic contributions to the management of apple scab. We conclude that AP use strategies developed under the climatic conditions of northern Europe do not apply fully to scab management under the climatic conditions of the Great Lakes or similar regions, and that mechanisms conferring low-level resistance to multiple fungicides including the DMIs may affect the relative performance of APs.

\section{ACKNOWLEDGMENTS}

This work was supported, in part, by the New York Apple Research and Development Program and by Bayer CropScience, Research Triangle Park, NC. We thank Juliet Carrol, David Rosenberger, and William Turechek for providing diseased leaf samples, and Christopher O'Donnell for technical assistance.

\section{LITERATURE CITED}

1. Babij, J., Zhu, Q., and Hollomon, D. W. 2000. Resistance risk assessment of cereal eyespot, Tapesilia yallundae and Tapesia acuformis, to the anilinopyrimidine fungicide, cyprodinil. Eur. J. Plant Pathol. 106:895-905.

2. Baroffio, C. A., Siegfried, W., and Hilber, U. W. 2003. Long-term monitoring for resistance of Botryotinia fuckeliana to anilinopyrimidine, phenylpyrrole, and hydroxyanilide fungicides in Switzerland. Plant Dis. 87:662-666.

3. Bower, K. N., Berkett, L. P., and Costante, J. F.
1995. Nontarget effect of a fungicide spray program on phytophagous and predacious mite populations in a scab-resistant apple orchard. Environ. Entomol. 24:423-430.

4. Brunelli, A., Gianati, P., Flori, P., and Berardi, R. 2003. Experimental trials on the activity of new fungicides against apple scab. Pflanzenschutz-Nachr. Bayer 56:259-280.

5. Chapeland, F., Fritz, R., Lanen, C., Gredt, M. and Leroux, P. 1999. Inheritance and mechanisms of resistance to anilinopyrimidine fungicides in Botrytis cinerea (Botryotinia fuckeliana). Pestic. Biochem. Physiol. 64:85-100.

6. Cremers, P. 1994. New curative fungicide families to control scab on pome fruits. Norweg. J. Agric. Sci. Suppl. 17:185-193.

7. Cremers, P., and VanMechelen, A. 1999. Managing fungal diseases on pome fruits in relation with anti-resistance strategies for modern fungicides. Pages 257-266 in: Modern Fungicides and Antifungal Compounds II. H. Lyr, P. E. Russel, H. W. Dehne, and H. D. Sisler, eds. Intercept, Andover, UK.

8. Daniels, A., Birchmore, R. J., and Winter, E. H. 1994. Activity of pyrimethanil on Venturia inaequalis. Pages 525-532 in: The BCPC Conference Pests \& Diseases 1994, Conference Proceedings, British Crop Protection Council, Farnham, Surrey, UK.

9. Daniels, A., and Lucas, J. A. 1995. Mode of action of the anilino-pyrimidine fungicide pyrimethanil. 1. In-vivo activity against Botritis fabae on broad bean (Vivicia faba) leaves. Pestic. Sci. 45:33-41.

10. Del Sorbo, G., Schoonbeck, H., and De Waard, M. A. 2000. Fungal transporters involved in efflux of natural toxic compounds and fungicides. Fungic. Genet. Biol. 30:1-15.

11. Dianez, F., Santos, M., Blanco, R., and Tello, J. C. 2002. Fungicide resistance in Botrytis cinerea isolates from strawberry crops in Huelva (southwestern Spain). Phytoparasitica 30:529-534.

12. Forster, B., and Staub, T. 1996. Basis for use strategies of anilinopyrimidine and phenylpyrolle fungicides against Botrytis cinerea. Crop Prot. 15:529-537.

13. Fritz, R., Lanen, C., Colas, V., and Leroux, P. 1997. Inhibition of methionine biosynthesis in Botrytis cinerea by the anilinopyrimidine fungicide pyrimethanil. Pestic. Sci. 49:40-46.

14. Hagley, E. A., and Biggs, A. R. 1989. Effects of three fungicides on populations of a phytophagous and several predacious mites acarina on apple. Exp. Appl. Acarol. 6:253-256.

15. Heye, U. J., Speich, J., Siegle, H., Steinemann, A., Forster, B., Knauf-Beiter, G., Herzog, J., and Hubele, A. CGA 219417: A novel broadspectrum fungicide. Crop Prot. 13:541-549.

16. Hilber, U. W., and Hilber-Bodmer, M. 1998. Genetic basis and monitoring of resistance of Botryotinia fuckeliana to anilinopyrimidines. Plant Dis. 82:496-500.

17. Hilber, U. W., and Schüepp, H. 1996. A reliable method for testing the sensitivity of Botryotinia fuckeliana to anilinopyrimidies in vitro. Pestic. Sci. 47:241-247.

18. Jones, A. L., Ehret, G. R., and Sundin, G. W. 2003. After-infection control of apple scab with strobilurins, 2002. Fungic. Nematicide Tests 58:PF002.

19. Jones, A. L., Ehret, G. R., and Sundin, G. W. 2003. Apple scab control with strobilurin fungicides applied on a protective schedule, 2002. Fungic. Nematicide Tests 58:PF003GG.

20. Knauf-Beiter, G., Dahmen, H., Heye, U., and Staub, T. 1995. Activity of cyprodinil: Optimal treatment timing and site of action. Plant Dis. 79:1098-1103.

21. Köller, W. 1991. Fungicide resistance in plant pathogens. Pages 679-720 in: CRC Handbook of Pest Management in Agriculture, 2nd ed. Vol. 2. D. Pimentel, ed. CRC-Press, Boca Raton, FL. 
22. Köller, W. 1999. Chemical approaches to managing plant pathogens. Pages 337-376 in: Handbook of Pest Management. J. R. Ruberson, ed. Marcel Dekker, New York.

23. Köller, W. 2001. Fungicide resistance. Pages 483-488 in: The Encyclopedia of Plant Pathology. O. C. Maloy and T. D. Murray, eds. John Wiley \& Sons, New York.

24. Köller, W. 2003. Mode of action of sterolinhibiting fungicides. Pages 628-640 in: The Encyclopedia of Agrochemicals. J. R. Plimmer, ed. John Wiley \& Sons, New York.

25. Köller, W., and Parker, D. M. 1989. Purification and characterization of cutinase from Venturia inaequalis. Phytopathology 79:278-283.

26. Köller, W., Parker, D. M., Turecheck, W. W., Avila-Adame, C., and Cronshaw, K. 2004. A two-phase resistance response of Venturia inaequalis populations to the QoI fungicides kresoxim-methyl and trifloxystrobin. Plant Dis. 88:537-544.

27. Köller, W., and Wilcox, W. F. 1999. Evaluation of tactics for managing resistance of Venturia inaequalis to sterol demethylation inhibitors. Plant Dis. 83:857-863.

28. Köller, W., and Wilcox, W. F. 2000. Interactive effects of dodine and the DMI fungicide fenarimol in the control of apple scab. Plant Dis. 84:863-870.

29. Köller, W., Wilcox, W. F., Barnard, J., Jones, A. L., and Braun, P. G. 1997. Detection and quantification of resistance of Venturia inaequalis populations to sterol demethylation inhibitors. Phytopathology 87:184-190.

30. Küng, R, Chin K. M., and Gisi, U. 1999. Sensitivity of Venturia inaequalis to cyprodinil. Pages 313-322 in: Modern Fungicides and Antifungal Compounds II. H. Lyr, P. E. Russel, H. W. Dehne, and H. D. Sisler, eds. Intercept, Andover, UK.

31. Kunz, S., Lutz, B., Deising, H., and Mendgen, K. 1998. Assessment of sensitivities to anilinopyrimidine- and strobilurin-fungicides in populations of the apple scab fungus Venturia inaequalis. J. Phytopathol. 146:231-238.

32. Latorre, B. A., Spadaro, I., and Rioja, M. E. 2002. Occurrence of resistant strains of Botrytis cinerea to aninilinopyrimidine fungicides in table grapes in Chile. Crop Prot. 21:957-961

33. Leroux, P., Chapeland, F., Desbrosses, D., and Gredt, M. 1999. Patterns of cross-resistance to fungicides in Botryotinia fuckeliana (Botrytis cinerea) isolates from French vineyards. Crop Prot. 18:687-697.

34. Leroux, P., Colas, V., Fritz, R., and Lanen, C. 1996. Interaction of the anilinopyrimidine fungicide pyrimethanil with amino acids and sulfur containing metabolites in Botrytis cinerea. Pages 61-67 in: Modern Fungicides and Anti- fungal Compounds. H. Lyr, P. E. Russell, and H. D. Sisler, eds. Intercept, Andover, UK.

35. Maeno, S., Miura, I., Masuda, K., and Nagata, T. 1990. Mepanipyrim (KIF-3535), a new pyrimidine fungicide. Pages 415-422 in: The BCPC Conference Pests \& Diseases 1990, Conference Proceedings, British Crop Protection Council, Farnham, Surrey, UK.

36. Masner, P., Muster, P., and Schmid, J. 1994. Possible methionine biosynthesis inhibition by pyrimidinamine fungicides. Pestic. Sci. 42:163-166.

37. Milling, R. J., and Richardson, C. J. 1995. Mode of action of the anilino-pyrimidine fungicide pyrimethanil. 2. Effects on enzyme secretion in Botrytis cinerea. Pestic. Sci. 45:4348.

38. Miura, I., Kamakura, T., Maeno, S., Hayashi, S., and Yamaguchi, I. 1994. Inhibition of enzyme secretion in plant pathogens by mepanipyrim, a novel fungicide. Pestic. Biochem. Physiol. 48:222-228.

39. Miura, I., Muroi, M., Shiragami, N., Yamaguchi, I., and Takatsuki, A. 1996. Effects of mepanipyrim on intracelluar trafficking: A comparative study on its effects on exocytic and endocytic trafficking of proteins, sphingolipids, and cholesterol. Biosci. Biotechnol. Biochem. 60:1690-1697.

40. Nakamura, M., Kono, Y., and Takatsuki, K. 2003. Mepanipyrim, a novel inhibitor of pharmacologically induced golgi dispersion. Biosci. Biotechnol. Biochem. 67:139-150.

41. Neumann, G. L., Winter, E. H., and Pittis, J. E. 1992. Pyrimethanil: A new fungicide. Pages 395-402 in: The BCPC Conference Pests \& Diseases 1992, Conference Proceedings, British Crop Protection Council, Farnham, Surrey, UK.

42. Parker, D. M., Hilber, U. W., Bodmer, M., Smith, F. D., Yao, C., and Köller, W. 1995. Production and transformation of conidia of Venturia inaequalis. Phytopathology 85:87-91.

43. Richter, D. L. 1987. Synergism - A patent view. Pestic. Sci. 19:309-315.

44. Rosslenbroich, H.-J., and Stuebler, D. 2000. Botrytis cinerea - history of chemical control and novel fungicides for their management. Crop Prot. 19:557-561

45. Schnabel, G., and Parisi, L. 1997. Sensitivity of Venturia inaequalis to five DMI fungicides, including the new triazole fluquinconazole, and to pyrimethanil. J. Plant Dis. Prot. 104:3646.

46. Schnabel, G., Schnabel, E. L., and Jones, A. L. 2002. Genes encoding multidrug resistance like proteins in V. inaequalis. Pages 297-305 in: Modern Fungicides and Antifungal Compounds III. H. W. Dehne, U. Gisi, K. H. Kuck,
P. E. Russell, and H. Lyr, eds. AgroConcept, Bonn, Germany.

47. Sierotzki, H., Wullschleger, J., Alt, M. Bruyére, T., Pillonel, C., Parisi, S., and Gisi, U. 2002. Potential mode of resistance to anilinopyrimidine fungicides in Botrytis cinerea Pages 141-148 in: Modern Fungicides and Antifungal Compounds III. H. W. Dehne, U. Gisi, K. H. Kuck, P. E. Russell, and H. Lyr, eds. AgroConcept, Bonn, Germany.

48. Smith, F. D., Parker, D. M., and Köller, W. 1991. Sensitivity distribution of Venturia inaequalis to the sterol demethylation inhibitor flusilazole: Baseline sensitivity and implications for resistance monitoring. Phytopathology 81:392-396.

49. Stensvand, A., Gadoury, D. M., Amundsen, T., Semb, L., and Seem, R. C. 1997. Ascospore release and infection of apple leaves by conidia and ascospores of Venturia inaequalis at low temperatures. Phytopathology 87:1046-1053.

50. Stergiopoulos, I., Zwiers, L.-H., and De Waard, M. A. 2002. Secretion of natural and synthetic toxic compounds from filamentous fungi by membrane transporters of the ATPbinding cassette and major facilitator superfamily. Eur. J. Plant Pathol. 108:719-734.

51. Vermeulen, T., Schoonbeek, H., and De Waard, M. A. 2001. The ABC transporter BcatrB from Botrytis cinerea is a determinant of the activity of the phenylpyrrole fungicide fludioxanil Pestic. Manage. Sci. 57:393-402.

52. Wilcox, W. F., Burr, J. A., and Heidenreich, G. 1999. Evaluation of fungicide programs for control of scab and powdery mildew of apples, 1998. Fungic. Nematicide Tests 54:31-32.

53. Wilcox, W. F., Burr, J. A., and Heidenreich, G. 2000. Evaluation of fungicide programs for control of scab and powdery mildew of apples, 1999. Fungic. Nematicide Tests 55:36-37.

54. Wilcox, W. F., Burr, J. A., and Heidenreich, G. 2001. Evaluation of fungicide programs for control of scab and powdery mildew of apples, 2000. Fungic. Nematicide Tests 56:PF37.

55. Wilcox, W. F., Burr, J. A., Heidenreich, G., Smith, C., and Gadoury, D. M. 1998. Evaluation of fungicide programs for control of scab and powdery mildew of apples, 1997. Fungic Nematicide Tests 53:37-38.

56. Wilcox, W. F., Burr, J. A., Smith, C. A., and Gadoury, D. M. 1997. Evaluation of fungicide programs for control of scab and powdery mildew of apples, 1996. Fungic. Nematicide Tests 52:38-39.

57. Wong, F. P., and Wilcox, W. F. 2002. Sensitivity to azoxystrobin among isolates of Uncinula necator: Baseline distribution and relationship to myclobutanil sensitivity. Plant Dis. 86:394 404. 